\title{
DEVELOPING FRAMEWORKS FOR STUDIES ON SEDIMENTARY FLUXES AND BUDGETS IN CHANGING COLD ENVIRONMENTS
}

\author{
ACHIM A. BeYLICH \\ Geological Survey of Norway (NGU), Quaternary Geology \& Climate group, Trondheim, Norway \\ Norwegian University of Science and Technology (NTNU), Department of Geography, Trondheim, Norway
}

SCOTT F. LAMOUREUX

Queen`s University, Department of Geography, Kingston, Canada

Armelle DeCAulne

Clermont Université, Université Blaise Pascal, GEOLAB, Clermont-Ferrand, France CNRS, UMR 6042, GEOLAB, Clermont-Ferrand, France

Manuscript received: October 15, 2010

Revised version: February 27, 2011

Beylich A.A., Lamoureux S.F. \& Decaulne A., 2011. Developing frameworks for studies on sedimentary fluxes and budgets in changing cold environments. Quaestiones Geographicae 30(1), Bogucki Wydawnictwo Naukowe, Poznań, pp. 5-18, 4 Figs. ISBN 978-83-62662-39-5. ISSN 0137-477X. DOI 10.2478/v10117-011-0001-5.

AвSTRACT. Geomorphic processes that are responsible for the transfer of sediments and landform change are highly dependent on climate and vegetation cover. It is anticipated that climate change will have a major impact on the behaviour of Earth surface systems and that the most profound changes will occur in high-latitude and high-altitude cold environments. Collection, comparison and evaluation of data from a range of different high-latitude and high-altitude cold environments are required to permit greater understanding of sedimentary fluxes in cold environments. The focus of the I.A.G./ A.I.G. SEDIBUD (Sediment Budgets in Cold Environments) Programme is the analysis of source-to-sink fluxes and sediment budgets in changing cold environments. Establishing contemporary sediment fluxes in a diversity of cold environments will form a baseline for modelling. At a minimum, baseline information from defined SEDIBUD test sites must consist of measures of mean annual precipitation, stream discharge, suspended load, conductivity/TDS and dominant catchment processes. Reports from ongoing studies on sedimentary fluxes and budgets in three selected study sites in Arctic Canada, subArctic Iceland and sub-Arctic Norway are presented and discussed in the context of effects of climate change on process rates and sediment budgets in sensitive cold environments. Comparable datasets and coordinated data collection and data exchange will be of use for the individual studies at the different study sites. In addition, comparable data sets and data exchange will help to improve our understanding of existing relationships between contemporary climate and sedimentary fluxes and will enable larger-scale integrated investigations on effects of climate change in changing cold environments.

KEYwORDs: climate change, cold environments, contemporary sediment fluxes and budgets, coordinated data collection and exchange, inter-site comparisons, monitoring

Beylich A.A., Geological Survey of Norway (NGU), Quaternary Geology \& Climate group, Leiv Eirikssons vei 39, NO-7491 Trondheim, Norway, e-mail: achim.beylich@ngu.no

Lamoureux S.F., Department of Geography, Queen's University, Kingston ON, K7L 3N6 Canada, e-mail: scott.lamoureux@queensu.ca

Dacaulne A., CNRS, UMR 6042, GEOLAB, 4 rue Ledru, F-63057 Clermont-Ferrand, France,

e-mail: armelle.decaulne@univ-bpclermont.fr 


\section{Introduction}

Geomorphologic processes that are responsible for the transfer of sediments and landform change are highly dependent on climate and vegetation cover. It is anticipated that climate change will have a major impact on the behaviour of Earth surface systems and that the most profound changes will occur in high-latitude and high-altitude cold environments (ACIA 2005), where temperature increases could lead to potentially irreversible shifts in hydrologic regime and geomorphologic processes (Beylich \& Warburton 2007, Beylich et al. 2008b, 2009a). It is critical to develop a better understanding of the mechanisms of sedimentary transfer processes currently operating in cold environments, their likely controls and the expected nature of responses to climate change. Quantitative analyses of sedimentary transfers have largely been confined to other climatic zones, and therefore integrated studies of source-to-sink sedimentary fluxes in cold environments are necessary to understand the likely sedimentary responses in cold regions. Collection, comparison and evaluation of data from a range of different high-latitude and highaltitude cold environments are required to permit greater understanding of sedimentary fluxes in cold environments. Given the diverse nature of existing research in cold environments, it is necessary to develop standardised methods and approaches for future research on sedimentary fluxes and relationships between climate and sedimentary transfer processes (Beylich \& Warburton 2007, Beylich et al. 2008b; 2009a, Lamoureux et al. 2007).

\section{The I.A.G. / A.I.G. SEDIBUD Programme}

The I.A.G./A.I.G. Working Group SEDIBUD (Sediment Budgets in Cold Environments) builds on activities, which were started within the European Science Foundation (ESF) Network SEDIFLUX (Sedimentary Source-to-Sink Fluxes in Cold Environments) (Beylich et al. 2006). The major aim of I.A.G./A.I.G. SEDIBUD is to provide an integrated quantitative analysis of sedimentary transfers, nutrient fluxes and sediment budgets across a range of cold environments. Such a coordinated analysis has so far been absent (Beylich et al. 2009a).

At the Second SEDIBUD Workshop which took place in Abisko (Sweden) in September 2007 the SEDIBUD group, building on the progress and the outcomes of ESF SEDIFLUX and I.A.G./ A.I.G. SEDIBUD since 2004, defined the following main focus of the SEDIBUD Programme:

"The focus of SEDIBUD is the analysis of sourceto-sink fluxes and sediment budgets in changing high latitude and high altitude cold environments. Explicit in this goal is the need to understand how processes and environments will respond to climate change. Space-for-time substitution offers the opportunity to predict future changes, but only if the baseline used is sound. At present we lack full understanding of contemporary sediment fluxes in cold environments. Establishing contemporary sediment fluxes in a diversity of cold environments can form a baseline from which modelling can operate. At a minimum baseline information must consist of measurements of mean annual precipitation, stream discharge, suspended load, conductivity/TDS, and dominant catchment processes" (I.A.G./ A.I.G. SEDIBUD Working Group, March 2010 http://www.geomorph.org/wg/ wgsb.html; see also Lamoureux et al. 2007, Beylich et al. 2008b, 2009a).

\section{Reports from three ongoing sediment budget studies in Arctic Canada, sub- Arctic Iceland and sub-Arctic Norway}

Sediment budgets studies carried out in different high latitude and high altitude environments are diverse with respect to focus, research questions addressed and methods used. With respect to the main focus of the SEDIBUD Programme, individual research projects carried out at selected study sites contribute to the overall programme by providing baseline data as mentioned above. In return, each individual project will have the opportunity to benefit from increased used of shared methods and the coordinated data exchange performed within SEDIBUD, which will enable inter-site comparisons.

Reports from ongoing studies on sediment fluxes and budgets in selected study sites in Arc- 
tic Canada, sub-Arctic Iceland and sub-Arctic Norway (Fig. 1) are presented and discussed in the context of effects of climate change on process frequencies, intensities, process rates and sediment budgets in sensitive cold environments. The three projects have different foci but they all provide baseline data of use for the overall SEDIBUD Programme. Additionally, these studies provide an indication of the range of SEDIBUD-related research currently underway in a wide variety of cold regions. The study in Arctic Canada provides an investigation on fluvial processes and can deliver required baseline data on mean annual precipitation, stream discharge, suspended sediment load and electric conductivity/TDS whereas the study in sub-Arctic Iceland has a focus on slope processes as dominant catchment processes. The investigation in sub-Arctic Norway includes both

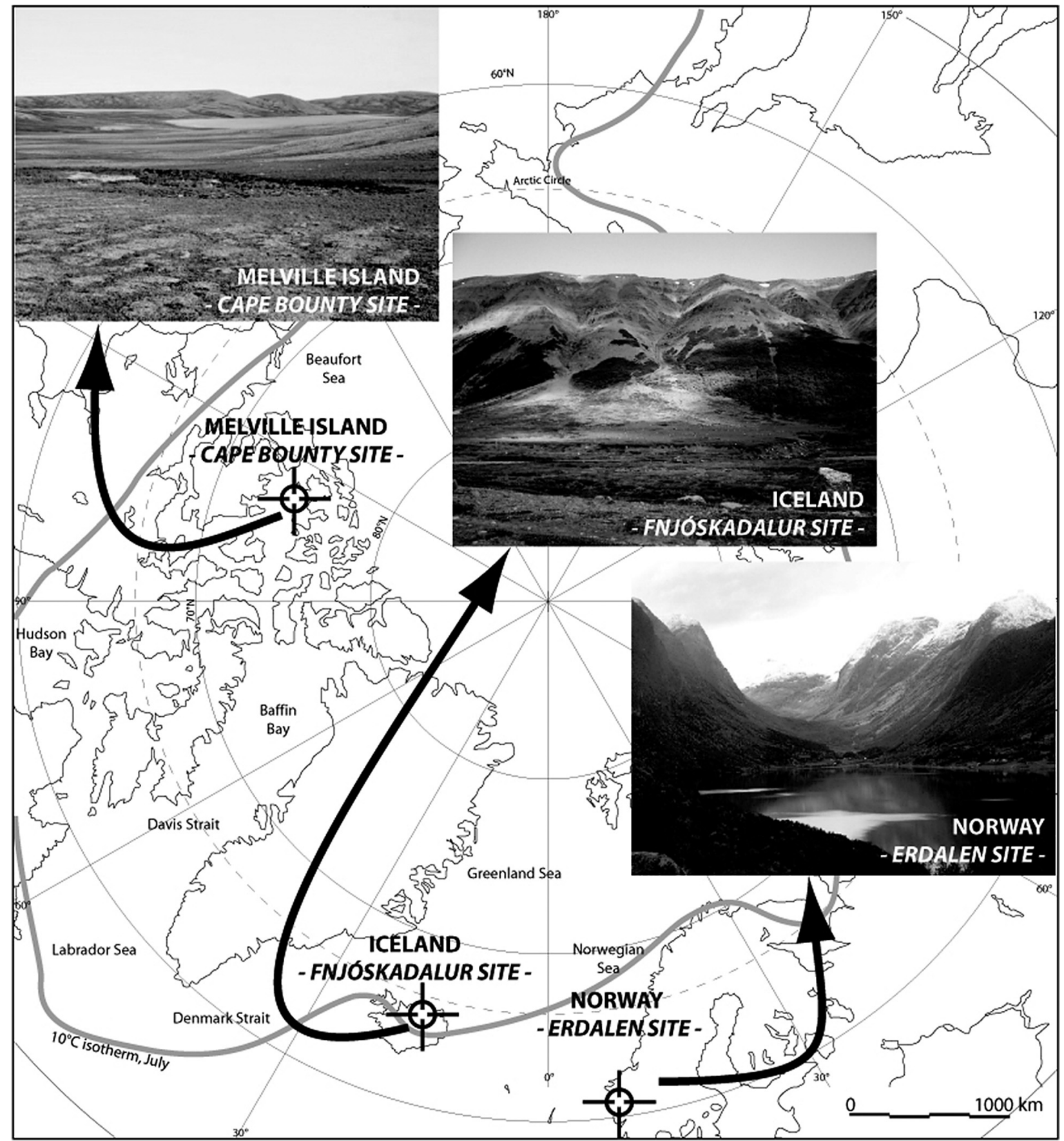

Fig. 1. Location of the three study sites in Canada (Cape Bounty), Iceland (Fnjóskadalur) and Norway (Erdalen) 
the fluvial and slope systems and can deliver the required baseline data described above (Fig. 1). Collection and compilation of comparable data sets from different cold environment catchment geosystems requires clear guidelines on instrumentation, sampling frequencies, etc. as well as carefully developed protocols to be filled in with the described baseline data by the responsible project leaders and made available for the SEDIBUD Programme (Beylich \& Warburton 2007).

The need for coordinated guidance on developing quantitative frameworks for characterising field-based studies on sedimentary fluxes and budgets in changing cold environments is indicated.

\section{Cape Bounty, Arctic Canada}

\section{Goals}

The Cape Bounty Arctic Watershed Observatory (CBAWO) is the longest comprehensive hydrological monitoring site in the Canadian Arctic Archipelago (Fig. 1). Established in 2003 on the south-central coast of Melville Island, near the Nunavut-Northwest Territories boundary $\left(74^{\circ} 55^{\prime} \mathrm{N}, 109^{\circ} 30^{\prime} \mathrm{W}\right)$, and operational on a seasonal basis, CBAWO comprises a series of paired watersheds at different scales (approximate 0.1, 1.0 and $10.0 \mathrm{~km}^{2}$ ). The region has been, and remains, uninhabited. Early geological work was carried out in the 1950s and 1960s (Hodgson et al. 1984), and petroleum exploration intensified during the 1970s. Since that time, the area has only been subject to rare scientific visits. Access is limited to April to September via charter aircraft from Resolute, Nunavut (450 km east).

The main research goal of CBAWO can be summarized as: what are the impacts of climate variability on High Arctic watershed processes and fluxes? The absence of substantial knowledge and long term monitoring of sediment, solute and related fluxes in this region remains acute and is similar to other global cold regions. Hence, this larger objective is approached through several major research strategies. First, contemporary processes and fluxes are systematically measured and supported by detailed manual samples of related sediment and hydrochemical parameters in two c. $10 \mathrm{~km}^{2}$ watersheds. As of 2007 , sediment fluxes have been monitored for five years, and hydrochemical fluxes for three years. This program was expanded to evaluate the fluxes from different terrain and vegetation types within smaller watersheds $\left(1 \mathrm{~km}^{2}\right)$. One of these watersheds was disturbed by an active layer detachment approximately $50+$ years ago and provides an indication of the impact of permafrost disturbance on fluxes. Finally, to evaluate the impact of projected increases in snowfall (ACIA 2005) on fluxes, paired experimental watersheds have been established (approximately $0.1 \mathrm{~km}^{2}$ each) and two were equipped with snow fences to augment snow cover for the 2008 season and beyond.

Second, determinations of long-term sediment fluxes are underway through the reconstruction of sedimentation in both the West and East lakes (unofficial names). Both lakes contain annuallylaminated (varved) sediments that allow measurement of annual sediment deposition. The sediment accumulation, calibrated by detailed lake sedimentation process research (e.g., Cockburn \& Lamoureux 2008), will be evaluated to determine long term sediment flux rates, variability, and the role of climate changes on sediment fluxes. The availability of long sedimentary records from two lakes will generate replicate records to evaluate localized variance in sediment fluxes between watersheds. Additional paleoenvironmental studies (of diatoms and pollen) and biogeochemical analyses will be generated from the sedimentary records as well.

\section{Study site and methods}

The landscape is composed of incised plateaux and hills with local relief up to $125 \mathrm{~m}$ (Figs 2a-c). Steeply dipping Upper Devonian sandstone and siltstone of the Franklinian Geosyncline underlie the study area and frost shattered bedrock is a common surficial material (Hodgson et al. 1984). Late Wisconsinan glaciation, along with early Holocene marine transgression over the glacio-isostatically depressed land, resulted in an extensive drape of glacial and marine sediments. Vegetation is highly heterogeneous, and ranges from near continuous wet sedge meadows to sparse polar desert communities (Atkinson \& 
Treitz 2007). The two main watersheds (unofficial names West and East) flow into freshwater lakes (maximum depth 30-34 m) that contain annually-laminated sediments (Fig. 2c) (Cockburn \& Lamoureux 2008).

The climate is cold and dry and typical of the High Arctic region. Mean January temperature is $-33.1^{\circ} \mathrm{C}$ and mean July temperature is $4.0^{\circ} \mathrm{C}$ at the closest long term meteorological station, Mould Bay, NWT (1971-2000, Environment Canada 2008). Total precipitation is $<150 \mathrm{~mm}$ at Mould Bay, and most falls as snow during the autumn and to a lesser extent, during the spring. Wind extensively redistributes snow into incised stream channels and other concavities, resulting in up to $4 \mathrm{~m}$ of channel snow and thin cover on exposed surfaces at the start of the melt season. Summer rainfall is typically of low intensity and large events $\left(>10 \mathrm{~mm} \mathrm{day}^{-1}\right)$ are rare (Environment Canada 2008). A comprehensive meteorological tower (MainMet) and two satellite stations record melt season conditions, and after 2005, year-round conditions (Figs 2a-d). Comprehensive snow surveys have been completed at the end of winter each year, and include forty 100-m long depth and density transects.

The melt season begins in early June and continues until mid-August. Stream flow commences in mid-June and maximum discharge typically occurs in late June or early July, and recedes to low flow by mid-July (Cockburn \& Lamoureux 2007). The presence of sedimentary bedrock and fine-grained surficial sediments results in relatively high suspended sediment concentrations during the nival freshet (500-10,000 $\mathrm{mg} \mathrm{l}^{-1}$ ) and lower concentrations during the baseflow period (50-200 $\mathrm{mg} \mathrm{l}^{-1}$ ) (McDonald \& Lamoureux 2009). A number of hydrometric stations collect melt season flow, turbidity, electrical conductivity and temperature data, and are supplemented by manual and pump samples for suspended sediment concentration, grain size, hydrochemistry, nutrients, and some contaminants (Figs 2a-c). Additionally, eight stations record soil temperature profiles and moisture throughout the year.

A host of related terrestrial measurements have been undertaken at CBAWO, and include: Vegetative biomass, soil and stream biogeochemical characterization, soil $\mathrm{CO}_{2}$ flux, soil carbon and nitrogen, and remotely sensed measurements of

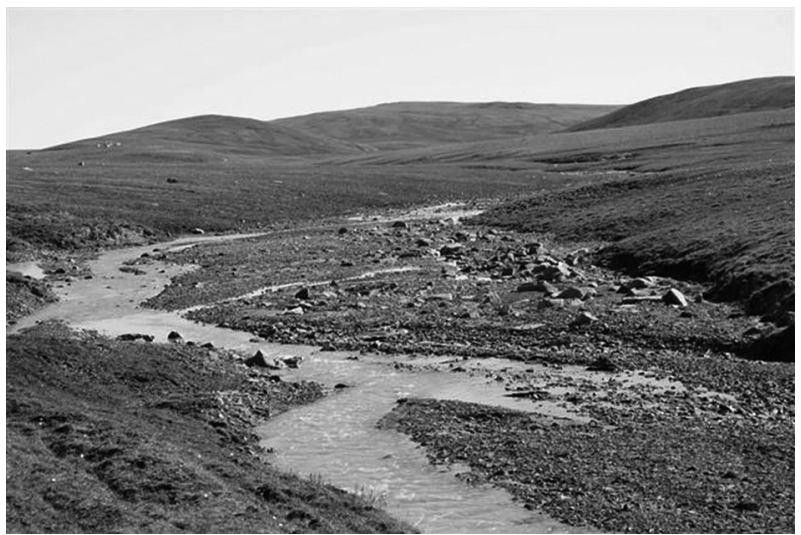

Fig. 2a. Landscape at Cape Bounty: West river channel during summer baseflow

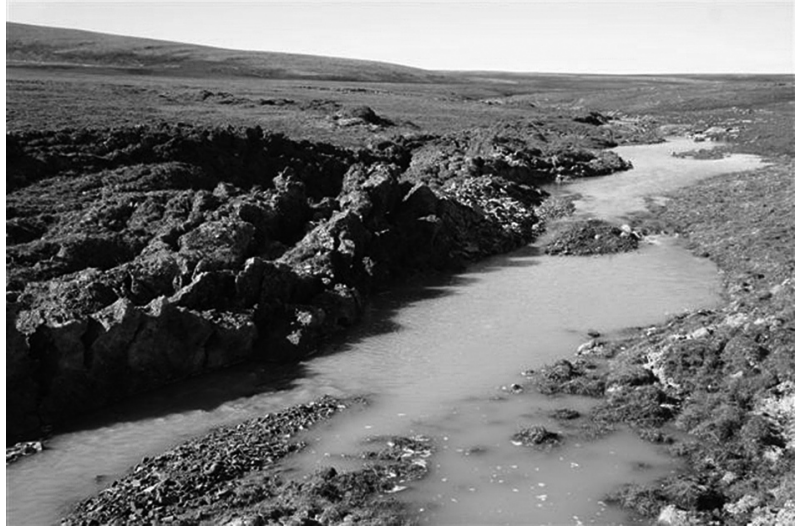

Fig. 2b. Landscape at Cape Bounty: Dam on West river channel caused by large active layer detachment during July 2007

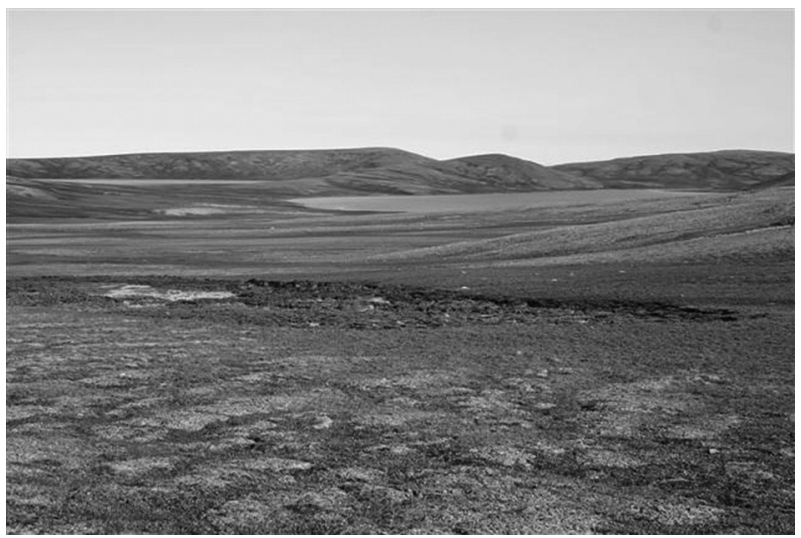

Fig. 2c. Landscape at Cape Bounty: Landscape with small active layer detachment

biomass and soil moisture with IKONOS and SAR imagery. Similarly, an extensive network of lake process monitoring is carried out and includes: sediment traps, water chemistry, instrument moorings (temperature, turbidity, electrical conductivity) and ecosystem sampling (diatoms). Long sediment cores (5-8 $\mathrm{m}$ ) have been recovered 
from both lakes to analyse sediment delivery and related paleoenvironmental records during the late Holocene.

\section{Results}

Initial results of sediment flux studies and nutrient studies have been recently reported (Lamoureux 2006, Cockburn \& Lamoureux 2007, Cockburn \& Lamoureux 2008, Lafrenière \& Lamoureux 2009, McDonald \& Lamoureux 2009). The main results to date are summarized below.

Early research in the Canadian High Arctic suggested that melt season air temperature was the primary control over runoff and sediment transport intensity (Hardy 1996). Subsequent work reported similar thermal controls on a diurnal basis, but noted that exhaustion of snow limited substantial sediment transport to the brief period of maximum discharge intensity (Forbes \& Lamoureux 2005). Results from Cape Bounty further demonstrate the crucial role of snow water equivalence (SWE) as a primary control over seasonal sediment yield (Cockburn \& Lamoureux 2007). Detailed analysis of the sediment transport hysteresis patterns suggest that clockwise hysteresis dominates in high SWE years and indicates some degree of sediment supply limitation (McDonald \& Lamoureux 2009). By contrast, low SWE years like 2005 were characterized by low sediment delivery intensity and seasonal yield, and counter-clockwise hysteresis suggested transport rather than supply limitations. Unfortunately, quantitative relationships between SWE and seasonal sediment yield will require long sediment monitoring records, as the available data has been insufficient to provide statistical constraint (Cockburn \& Lamoureux 2007).

Multi-year monitoring has also refocused attention towards sediment storage and release in the channel system, as well as the role of the thick channel snowpack in isolating the stream flow from the channel bed and bank (Lamoureux et al. 2006, McDonald \& Lamoureux 2009). Additionally, meltwater ponds that form behind snowdrift dams were demonstrated to result in substantial sediment storage on multi-year channel snowpacks. Lamoureux et al. (2006) noted that a large deposit of sediment formed during the spring of 2003, and part remained for two or more subsequent seasons. Hence, in this example, thick snowpack in the channel contributes an additional multi-year sediment storage mechanism with the potential to affect subsequent seasonal yields.

\section{Future directions}

The CBAWO has benefited from five years of detailed sediment and related monitoring research and represents the longest comprehensive record from the North American Arctic. Additional research activities have been added to extend terrestrial studies in the watersheds and contaminant fluxes in the rivers. International Tundra Experiment (ITEX, Molau et al. 2001) plots and open topped chambers (OTC) were established at Cape Bounty in 2008 to link plant responses to climate variability to hydrological and geomorphic fluxes.

Exceptionally warm summer temperatures in 2007 resulted in extensive ground ice melt and widespread active layer detachments in the West watershed (Lamoureux \& Lafrenière 2009). Hence, an important research focus will be to evaluate the watershed response to permafrost disturbances in the West and compare these results to the relatively undisturbed East watershed. Additionally, several large active layer detachments will be added to the stream gauging network to provide quantitative sediment and solute flux determinations. Additional work to investigate bedload transport, ground ice conditions and sediment stores and sinks will be undertaken.

\section{Fnjóskadalur, Iceland}

\section{Study area}

The Fnjóskadalur valley is a representative U-shaped valley in sub-Arctic Northern Iceland (Figs 1 and $3 a-d$ ), characterised by a wide range of denudative surface processes. The western side of the valley is dominated by large postglacial landslides, while snow avalanches and debris flows are particularly active on the east- 
ern side. This recurrent post-glacial activity has built large colluvial cones below a high rockwall (Fig. 3a). Field evidence indicates the occurrence of snow avalanches during recent decades, such as scattered transported boulder at a long distance of the slope toes and boulder accumulation at the end of the avalanche path (Figs. $3 b-d)$. Moreover, the tree cover on slopes, talus and cones permits an innovative dendrogeomorphological approach to the snow avalanche activity in Northern Iceland, leading to interesting dating of recent events. Several well-defined catchments ranging from 200 to $900 \mathrm{~m}$ asl can be studied. The study currently focuses on three colluvial cones.

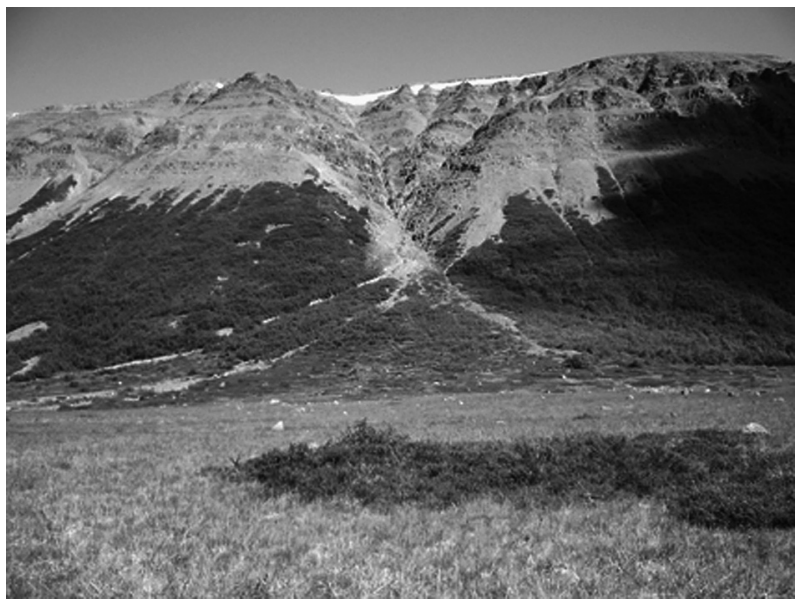

Fig. 3a. Landscape in Fnjóskadalur: One of the colluvial cones investigated

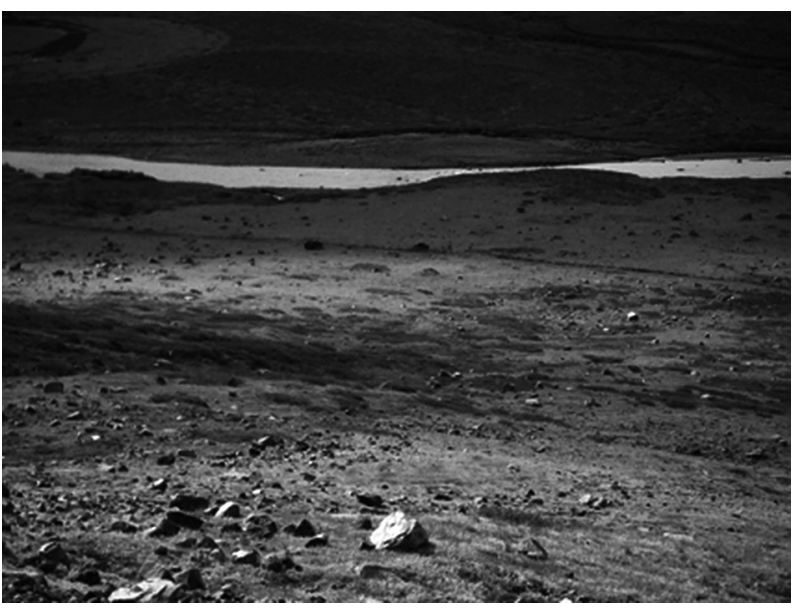

Fig. 3c. Landscape in Fnjóskadalur: The distal part of the cones covered with debris originating from recent snowavalanche activity

\section{Goals}

The study of the Fnjóskadalur colluvial cones aims to increase our knowledge about contemporary slope processes (mainly snow avalanches and debris flows), magnitude and frequency relationships and quantifying the sediment budget. This research also highlights the temporal variability of slope dynamics during the Holocene through analyses of sedimentary units such as colluvial cones.

Two time scales are therefore investigated in this area. At the present-time scale, the goals are (i) to obtain data regarding slope dynamics, the resulting sediment fluxes and the landscape impacts,

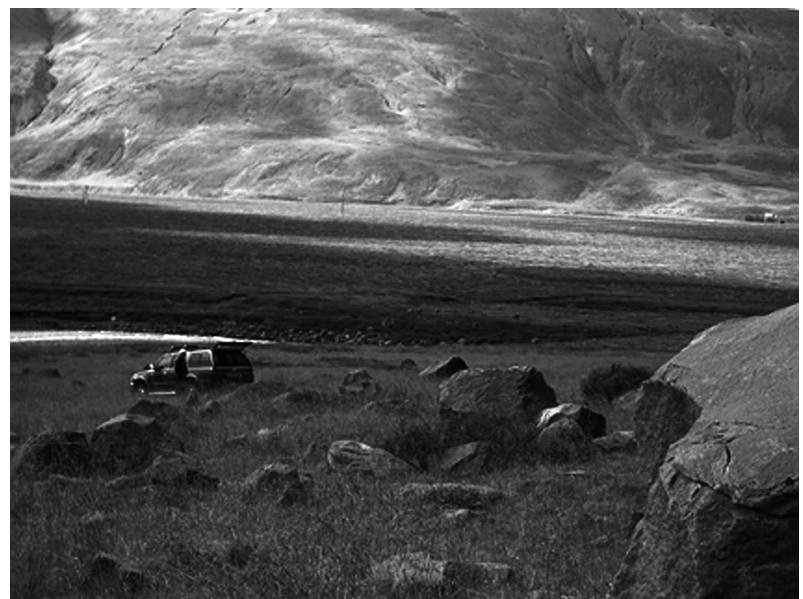

Fig. 3b. Landscape in Fnjóskadaur: Snow-avalanche transported boulders scattered in the distal part of one of the colluvial cones; note the car and person for scale

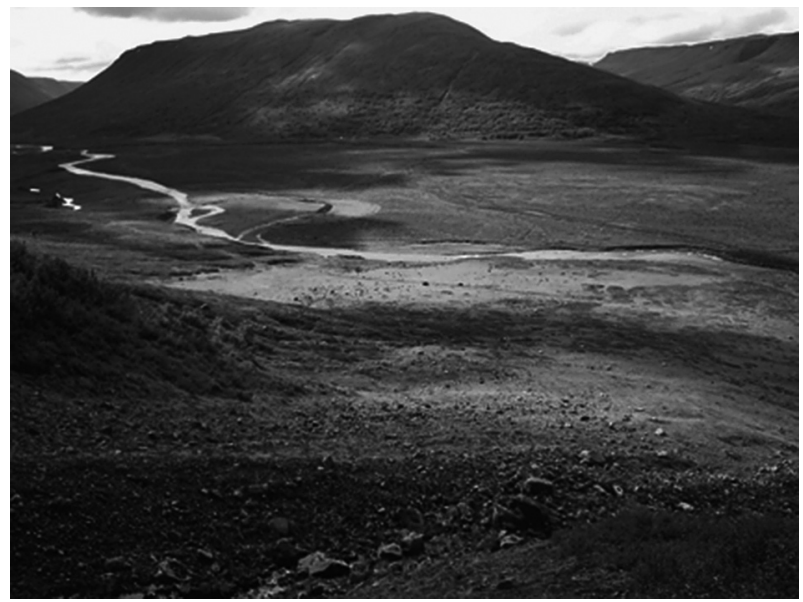

Fig. 3d. Landscape in Fnjóskadaur: A view of the large valley bottom and the steep valley walls 
and (ii) to enhance hazard assessment regarding the behaviour of potentially destructive events outside residential areas where reliable geomorphic evidence is lacking, and then to transfer the results to inhabited sectors. There is a special survey of snow-avalanche-transported (Decaulne \& Sæmundsson 2007, Decaulne et al. 2008, Decaulne \& Sæmundsson 2010). At the Holocene time scale, the colluvial cones record long-term activity occurring on slopes: the knowledge of past slope activity provides evidence on the changes that can be expected given the present climate modifications, by highlighting the previous time spans favourable for cone development (Decaulne et al. 2009).

\section{Methods}

Currently applied methods cover both topographical and geomorphologic approaches. Longitudinal profiles of the cones in the main axis of the flows were carried out, with a succession of 10 $m$ sections, to underline erosion and accumulation areas. Geomorphological maps were also drawn, recognising the different geomorphological units and related slope dynamics. The extreme reach and lateral spreading of slope dynamics were also mapped (Decaulne \& Sæmundsson 2005).

Several techniques are used to obtain different kinds of dating relevant to the way the cones were built. To date, research efforts were mainly focused on dendrogeomorphological and tephrochronological approaches.

Phytogeographical techniques (vegetation cover, lichenometry, dendrogeomorphology and dendrochronology) are of specific use for the recognition of recent activity on the slopes. The absolute and relative dates obtained range from a few years to over 150 years, covering the post Little Ice Age period particularly well. Phytogeography precisely locates the present-day most active paths.

Weathering analyses are used for relative dating of rocky deposits on the slope, especially on debris flow levees. These help to locate the succession of debris-flow migrations on the colluvial cones. Schmidt hammer tests extend the dating over 100 years.

Tephrochronology permits dating of sediment fluxes on the colluvial cones up to ca. 7000
$\mathrm{BP}$, covering a large part of the Holocene period. It benefits from the recurrent ash falls in the area during the Holocene period. The historical period is particularly rich, with up to five dated sequences (Decaulne et al. 2009).

\section{Results}

\section{Dendrogeomorphology}

The morphology of trees on the colluvial cones investigated shows the strong influence of slope processes on the trunks. By recording the orientation of trunk tilting, and the location of scars on the trunks, one can determine the origin and direction of sediment fluxes on the colluvial cones. Most of the injuries are attributed to snow avalanche occurrence when observed above 50 $\mathrm{cm}$ from the slope surface: there, the debris that caused the scars is not visible any longer. Numerous trunk deformations are also due to debris flows, inflecting damages to the lower part of trunks.

The size of the trunks, especially their diameters, permits recognition of the main paths followed by slope processes (Decaulne \& Sæmundsson 2008, Decaulne 2010).

In addition to their relevance to a geomorphologic fluxes perspective at the present-time, these results also have an indirect implication for natural hazards assessment. They highlight the potential spatial extent of geomorphic events on the cones (lateral component) as well as the position of potentially destructive boulders (vertical component: in the distal part of the cones some trees exhibit damage up to a height of $2 \mathrm{~m}$ ).

\section{Dendrochronology}

The trees cover in the valley shows an interesting synchronisation with the climate fluctuations during the past decades (Levanic \& Eggertsson 2008). The recent investigations tend also to link snow avalanche activity to a growth disturbance signal for the trees on the colluvial cones (Decaulne \& Sæmundsson 2008); especially, the numerous 1995 snow avalanche effects on trees are visible (Decaulne 2010). Sediment fluxes can therefore be dated on the colluvial cones at the tree life span, i.e. ca. 100 years. However, further investigations have to be carried out to corrobo- 
rate these preliminary results, and the work is in progress.

\section{Tephrochronology}

Dating of the different sequences observed on one of the colluvial cones in Fnjóskadalur valley reveals its rapid development (Decaulne et al. 2009). Sediments originating from slope processes appear to have been very important during historical time, as shown by the observed sequence in the distal part of the cone. Especially, a significant contribution from post-1262 $\mathrm{AD}$ debris flows is observed in this distal part. In the median part of the cone, the upper section records post-2900 BP debris flow deposits, while the previous period was not prone to significant slope activity: only scattered large boulders are observed, revealing chiefly a snow avalanche contribution. The thick sequences of aeolian soils are evidence of a cold climate.

These first results need to be compared with other profiles to get a more accurate idea of the sediment budget in the area.

\section{Erdalen, Norway}

\section{Study area}

Erdalen is a very steep U-shaped valley in the fjord landscape of western Norway (Nordfjord) (Figs 1 and 4a-d). The sub-Arctic Erdalen catchment, located at $61^{\circ} 50^{\circ} \mathrm{N}, 07^{\circ} 10^{\circ} \mathrm{E}$, is connected to the Jostedalsbreen ice cap and its uppermost parts still contain glacier ice. Detailed studies on Holocene, sub-recent and present-day sedimentary fluxes and sediment budgets were started in 2004 (Beylich et al. 2008a, 2009b, 2010, Hansen et al. 2009).

The Nordfjord area has been repeatedly occupied by glaciers during the Pleistocene. The mouth of Nordfjord was deglaciated at about 12.3 ka BP (Larsen \& Mangerud 1981). A pronounced Pre-Boreal moraine ridge formed during the socalled Erdalen-Event in Erdalen (Nesje 1984). During the thermal climatic optimum from 7000 to 4000 yrs BP the Jostedalsbreen ice cap disappeared for about 800 years (e.g. Nesje \& Kvamme 1991, Nesje et al. 1991, 2000, 2001). It reformed in the Neoglacial, coming to a maximum during the
Little Ice Age (LIA) around 1750 AD (Bickerton \& Matthews 1993). The LIA-moraine is situated only $1 \mathrm{~km}$ up-valley from the Erdalen moraine.

The present-day landscape in the Nordfjord area provides the impression of a young, mainly glacial valley topography cut into an old, "mature" land surface represented by plateau like mountain forms (Fareth 1987). The Erdalen valley is typical for this region and is deeply incised into bedrock (mainly gneisses); adjacent summits are up to 1200-1500 metres above the valley floor (Figs $4 a-d)$. The width of the latter varies along the valley but rarely exceeds $700 \mathrm{~m}$. Bedrock exposed across the valley bottom forms natural thresholds or sills controlling the incision of the main stream and creates natural boundaries between interconnected valley basins. Along the valley walls, bedrock alternates with talus cones, alluvial and colluvial fans (Figs 4a-d). A small glacial lake occupies the innermost valley basin at the margin of the present glacier. This lake is situated at $880 \mathrm{~m}$ a.s.l. and drains across a bedrock sill. The Erdalen glacier margin was located at this threshold in 1943; the glacier margin has been generally retreating since then and the lake developed (Nesje 1984). Between $460 \mathrm{~m}$ a.s.l. and $480 \mathrm{~m}$ a.s.l. a gravelly braid plain or sandur is developed, $1600 \mathrm{~m}$ long and up to $700 \mathrm{~m}$ wide (Fig. $4 c)$.

Ongoing studies on contemporary sediment fluxes are focussed on the upper Erdalen valley, covering an area of ca. $50 \mathrm{~km}^{2}$ from the outlet of the braided sandur system at $460 \mathrm{~m}$ a.s.l. to the highest parts of Erdalen at $1888 \mathrm{~m}$ a.s.l. Downvalley Erdalen terminates at lake Strynevatnet. (Fig. 4a).

Annual precipitation at the closest meteorological station with a long-term record (Oppstryn) is about $1100 \mathrm{~mm}$, with most precipitation occurring in fall and winter. The mean annual temperature at Oppstryn $\left(61^{\circ} 54^{`} \mathrm{~N}, 0^{\circ} 03^{`} \mathrm{E} ; 50\right.$ $\mathrm{m}$ a.s.l.) is $5.7^{\circ} \mathrm{C}$, with January being the coldest month with $-0.9^{\circ} \mathrm{C}$ and July being the warmest month with $14.2^{\circ} \mathrm{C}$ (Norwegian Meteorological Institute)

Present-day denudative processes include rock and boulder falls, avalanches, slush flows, debris flows, creep processes, wash denudation, chemical denudation and fluvial transport. The runoff regime is complex with runoff peaks oc- 


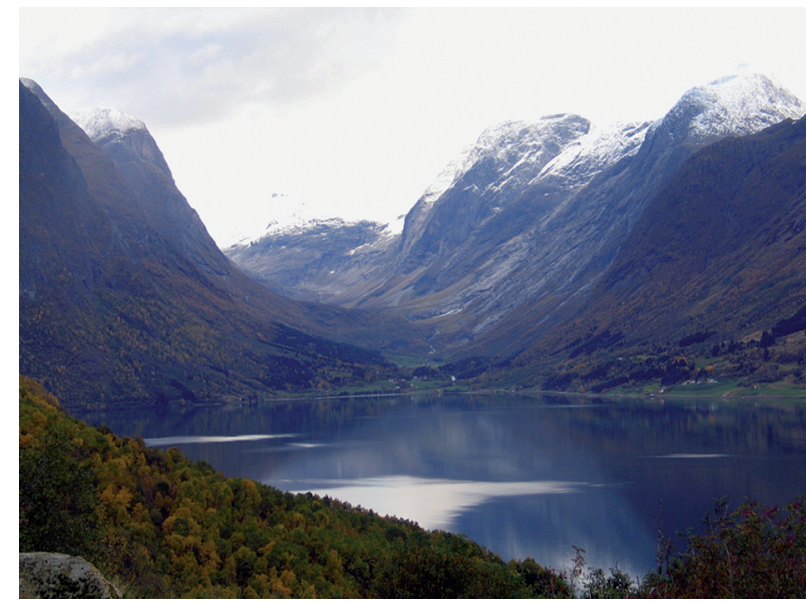

Fig. 4a. Landscape in Erdalen: The U-shaped Erdalen valley

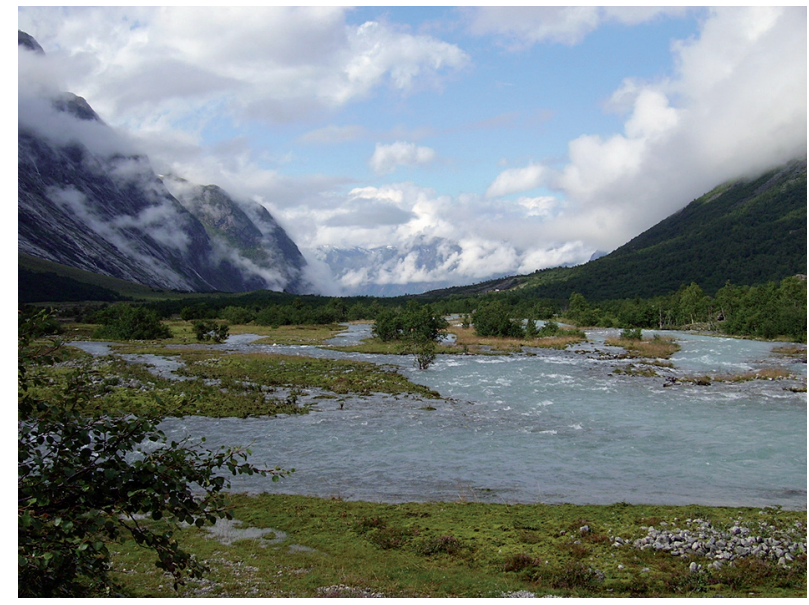

Fig. 4c. Landscape in Erdalen: The braided sandur system in upper Erdalen

curring during spring snowmelt, summer glacier melt and heavy rainfall events. Significant bedload transport occurs only during high runoff events. (Beylich et al. 2009, 2010)

\section{Goals and methods}

Research in Erdalen is focussed on a typical fjord-valley system. The aims are:

- To analyse how the inheritance of the landscape due to the influence of the Last Glacial Maximum (LGM) has affected process rates over time (paraglacial system)

- To document changes in process rates over different timescales by combining quantitative knowledge on Holocene process rates

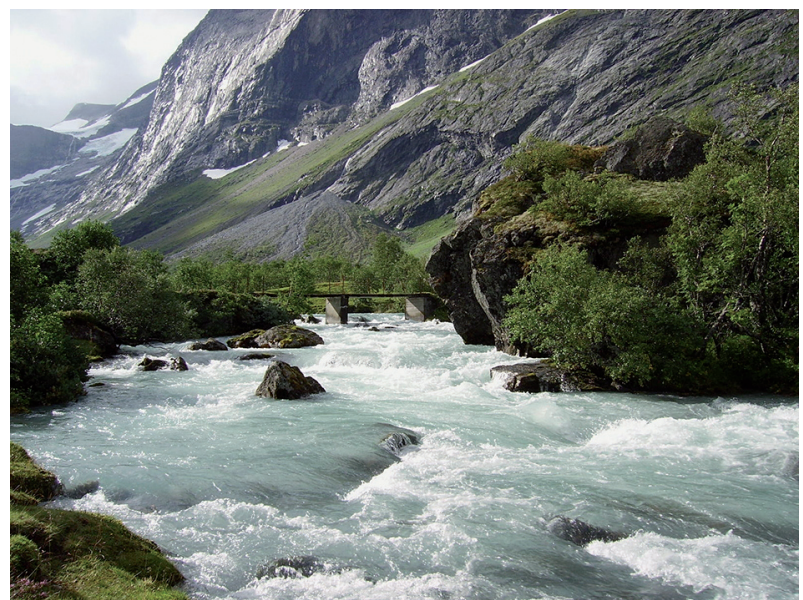

Fig. 4b. Landscape in Erdalen: Slope and fluvial systems in Erdalen

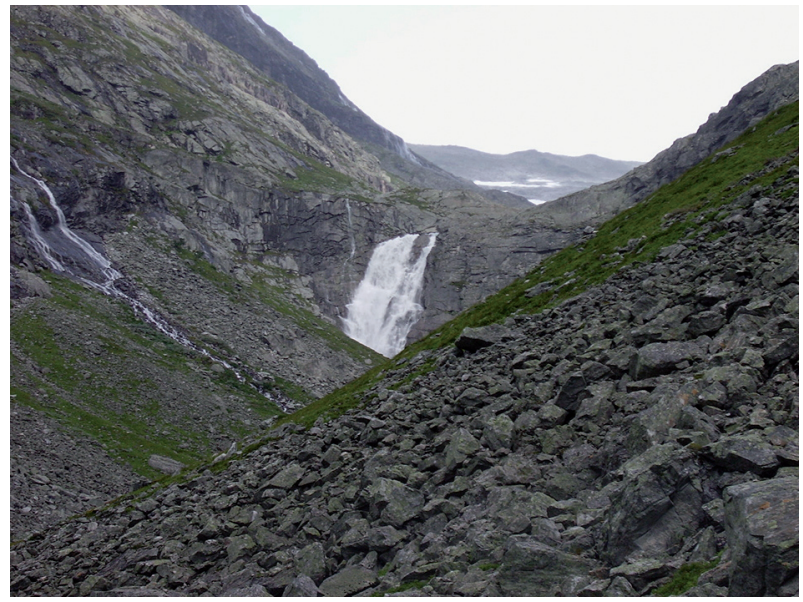

Fig. 4d. Landscape in Erdalen: Coupling between slope and fluvial system in uppermost Erdalen

with data on sub-recent and present-day process rates.

Investigations since 2004 include the analysis of storage elements (both architecture and volumes) by using geophysical techniques and by the year-round monitoring of meteorological parameters, ground temperature, runoff, fluvial solute and suspended sediment transport using stationary stations, as well as the analysis of fluvial bedload transport and slope processes like rock falls, avalanches and debris flows by combining different monitoring and dating techniques.

Investigations on volumes and architectures of storage elements (valley fillings, talus cones) are performed using different geophysical methods like georadar and seismic refraction sur- 
veys to improve the quantitative knowledge on Holocene process rates (Hansen et al. 2009).

Geomorphologic mapping of source, transfer and deposition areas as well as vegetation mapping were carried out and the maps were interpreted in combination with digital elevation models and data (Beylich et al. 2009b, Laute \& Beylich 2010).

Present-day sediment flux data are established by a monitoring programme in Erdalen including five automatic stations for continuous and year-round monitoring of water level, turbidity and electric conductivity. In addition an automatic weather station is in operation providing continuous data on wind speed and direction, air temperature, radiation, precipitation, snow cover thickness and ground temperatures at different depths. The monitoring programme, in combination with repeated analyses of surface water chemistry, atmospheric solute inputs and granulometry of suspended sediments, provides high-resolution data to analyse and quantify present-day sedimentary and solute fluxes (Beylich et al. 2009b, 2010). Also informationon the spatio-temporal variability of sediment sources, denudation rates and meteorological and topographic/landscape morphometric controls of denudative processes within the catchment. is delivered (Liermann et al. 2010) In addition to standard methods for monitoring bedload transport (marked stone tracers, magnet tracers) additional techniques like shock sensors (Vatne et al. 2008) and biofilm analysis (Gintz et al. 2008, e.g. Stevenson 2007) are applied to analyse channel stability/mobility and the range of bedload transport in Erdalen (Beylich et al. 2008a, 2009b).

Ongoing studies include the quantification of subrecent erosion and sedimentation rates (following the Little Ice Age) within the braided sandur system in upper Erdalen by using a combination of granulometric/channel morphometric analyses (Wache \& Beylich 2006, Beylich et al. $2009 \mathrm{~b}),{ }^{14} \mathrm{C}$ dating and granulometric analyses of flood deposits, dendrochronology and detailed geomorphic and vegetation mapping (Laute \& Beylich 2010). Current analyses of slope processes include stratigraphic analyses and ${ }^{14} \mathrm{C}$ dating of colluvium as well as detailed geomorphic and vegetation mapping, dating of rock fall de- bris using lichenometry, photo documentation, photogrammetry, Lidar and direct monitoring of denudative processes (e.g. collecting avalanche deposits on artificial planes, measuring creep rates using painted stone lines, etc.). (Laute \& Beylich 2010, Laute et al. 2010, Beylich et al. 2009b)

\section{Preliminary results and further studies}

The geophysical surveys permit determination of the depth of bedrock beneath the lake- and valley-fill deposits, as well as the extent and volume of the main valley-fill components (Hansen et al. 2006, Hansen et al. 2009).

The braided sandur system at Sandane is characterised by coarse deposits built up in a period of increased sediment delivery - including both newly produced and recycled old material - during the Little Ice Age (LIA) advance. In the down-valley part of this braided sandur system younger fine-grained flood sediments cover the Holocene valley infill.

The upper part of Sandane is characterised by a negative sub-recent sediment balance, with erosion of the coarse sediments from the Little Ice Age advance and downcutting of channels (Fig. 4c). In comparison, the lower part of Sandane has a balanced to slightly positive sub-recent sediment budget with formation of the younger flood sediments and more stable channels. Altogether, the sub-recent sediment budget of Sandane, following the Little Ice Age advance, appears to be slightly negative.

Contemporary coupling of slope and fluvial systems in Erdalen is limited and only a rather small amount of material is directly transported from the slopes into the main channels. Sediments from upstream tributaries are transported through the upper part of Sandane without storage. Apart from flood deposits, material is only temporarilly stored in channels in the lower part of Sandane before export during peak-runoff. Altogether, fluvial sediment transport appears to be supply-limited (Beylich et al. 2008a, 2009b, 2010, Laute \& Beylich 2010).

Further studies in Erdalen will continue the ongoing monitoring activities with the long-term and high-resolution analysis of present-day sediment fluxes and their controls, both meteorologi- 
cal and topographic / landscape morphometric (Beylich et al. 2010).

\section{Discussion and conclusion}

The field-based investigations at the three different study sites in Arctic Canada (Cape Bounty), sub-Arctic Iceland (Fnjóskadalur) and sub-Arctic Norway (Erdalen) are analysing rates and controls of sedimentary fluxes and budgets at different timescales (Holocene, sub-recent and contemporary) and assessing the effects of climate change on process rates and budgets.

Given the diversity of research questions addressed and methods used within the individual studies, there is an obvious need for coordinated guidance on developing quantitative frameworks for characterisation of catchment (field-based) sediment budget studies, so that: (1) baseline measurements at defined SEDIBUD test sites are standardised thus enabling inter-site comparisons, and (2) long-term changes in catchment geosystems related to climate change are well documented.

The SEDIFLUX Manual (Beylich \& Warburton 2007) in combination with SEDIBUD Protocols have been developed to serve as a framework to permit the collection and compilation of comparable data sets on baseline meteorological parameters and contemporary sedimentary fluxes from a wide range of cold environment catchment geosystems (Lamoureux et al. 2007, Beylich et al. 2008b, 2009a).

The comparable datasets and coordinated data exchange will be of use for the detailed individual studies at the different study sites. In addition, comparable data sets and data exchange will help to improve our understanding of existing relationships between contemporary climate and sedimentary fluxes and will enable larger-scale integrated investigations on effects of climate change on contemporary sediment fluxes in changing high latitude and high altitude cold environments. Comparable datasets from defined SEDIBUD test sites (I.A.G./ A.I.G. SEDIBUD Working Group, March 2010 http:/ / www. geomorph.org/wg/wgsb.html, Lamoureux et al. 2007, Beylich et al. 2008b, 2009a) will be compiled in the SEDIBUD Metadata Database. This is being developed to model effects of projected climate change on solute and sedimentary fluxes in changing high-latitude and high-altitude cold environments.

\section{Acknowledgements}

Work at Cape Bounty was supported by funding from the Natural Science and Engineering Research Council (NSERC), ArcticNet and the Canadian International Polar Year Program. Field logistical assistance was provided by the Polar Continental Shelf Project (PCSP), Natural Resources Canada. Work in Fnjóskadalur was supported by the Natural Research Centre of Northwest Iceland, Sauðárkrókur, Iceland, the French Arctic Research Group CNRS-GDR3062, Besançon, France and the Laboratory of Physical and Environmental Geography Geolab CNRSUMR6042, Clermont-Ferrand, France. Work in Erdalen was supported by funding from the Norwegian Research Council (NFR), the Geological Survey of Norway (NGU), the Norwegian University of Science and Technology (NTNU) and the German Exchange Service (DAAD). We thank our SEDIBUD colleagues for useful discussions. The helpful comments of two reviewers improving this paper are greatly acknowledged.

\section{References}

Arctic Climate Impact Assessment (ACIA) - Scientific Report, 2005. Arctic Climate Impact Assessment. Cambridge University Press, Cambridge: 1042 p.

Anderson J.B., 1999. Antarctic Marine Geology. Cambridge University Press, Cambridge: 289 p.

AtKInson D.M. \& Treitz P.M., 2007. Ecological classifications derived from spectral and vegetation data for Cape Bounty, Melville Island. Proceedings of IPY GeoNorth - International Circumpolar Conference on Geospatial Sciences and Applications, presented in Yellowknife, NWT, August 20-24.

Beylich A.A. \&. Warburton J., (eds.) 2007. Analysis of Sourceto-Sink-Fluxes and Sediment Budgets in Changing HighLatitude and High-Altitude Cold Environments. SEDIFLUX Manual. NGU Report 2007.053: 158 p.

Beylich A.A., Etienne S., Etzelmüller B., Gordeev V.V., KÄYHKÖ J., RAchold V., Russell A.J., Schmidt K.-H., SÆMUndSSON P., TweEd F.S. \& WARburTon J., 2006. The European Science Foundation (ESF) Network SEDIFLUX - an introduction and overview. Geomorphology 80(1-2): 3-7.

Beylich A.A., Hansen L., Liermann S., Gintz D., Laute K., Vatne G., Fredin O., Burki V., Berthling I. \& Schmidt K.- 
H., 2008a. Sub-recent sediment dynamics and sediment budget of the braided sandur system at Sandane, Erdalen (Nordfjord, Western Norway). Geophysical Research Abstracts. Vol. 10, EGU2008-A-02591, 2008.

Beylich A.A., Lamoureux S.F. \& Decaulne A., 2008b. SEDIBUD - Sediment Budgets in Cold Environments: Introduction. Zeitschrift für Geomorphologie N.F. 52(1): 1-2.

Beylich A.A., Lamoureux S.F. \& Decaulne A., 2009a. Sediment budgets in cold environments - The SEDIBUD Program. Introduction. Arctic, Antarctic, and Alpine Research 41(1): 1-2.

Beylich A.A., Laute K., Liermann S., Hansen L., Burki V., VatNE G., Fredin O., GintZ D. \& Berthling I., 2009b. Subrecent sediment dynamics and sediment budget of the braided sandur system at Sandane, Erdalen (Nordfjord, western Norway). Norwegian Journal of Geography 63(2): 123-131.

Beylich A.A., LiermanN S. \& LaUte K., 2010. Fluvial transport during thermally and pluvially induced peak runoff events in a glacier-fed mountain catchment in western Norway. Geografiska Annaler A 92(2): 237-246.

Bickerton R.W. \& Matthews J.A., 1993. 'Little Ice Age`variations of outlet glaciers from the Jostedalsbreen ice-cap, southern Norway: a regional lichenometric-dating study of ice-marginal moraine sequences and their climatic significance. Journal of Quaternary Science 8(1): 45-66.

BIRKENMAJER K. 1991. Tertiary glaciation in the South Shetland Islands, West Antarctica: evaluation of data. In: Thomson M.R.A., Crame J.A. \& Thomson J.W. (eds.), Geological Evolution of Antarctica. Cambridge University Press, Cambridge: 629-632.

Cockburn J.M.H. \& LAMOUREux S.F., 2007. Hydroclimate controls over seasonal sediment yield in two adjacent high arctic watersheds. Hydrological Processes, DOI: 10.1002/ hyp. 6798

Cockburn J.M.H. \& LAmoureux S.F., 2008. Inflow and lake controls on short-term mass accumulation and sedimentary particle size in a High Arctic lake: implications for interpreting varved lacustrine sedimentary records. Journal of Paleolimnology 40: 923-942.

Decaulne A., 2010. Dendrogéomorphologie et dendrochronologie en Islande septentrionale : le bouleau révélateur de l'activité avalancheuse. In: Surdeanu V., Stoffel M. \& Pop O. (Coord.): Dendrogéomorphologie et dendroclimatologie - Méthodes de reconstitution des milieux géomorphologiques et climatiques des régions montagneuses, Universitatea Babeş-Bolyai, Presa Universitară Clujeană: 61-80.

Decaulne A. \& Sæmundsson TH., 2005. Geomorphological investigations in the Fnjóskadalur and Bleiksmýrardalur valleys, north Iceland: snow-avalanches impact on slopes. Náttúrustofa Norðurlands vestra NNV05003: $17 \mathrm{p}$.

Decaulne A. \& Sæmundsson Th., 2007. The role of geomorphological evidence for snow-avalanche hazard and mitigation research in northern Icelandic fjords. In: Schaefer V.R., Schuster R.L. \& Turner A.K. (eds.), First North America Landslide Conference, Vail, Colorado, AEG Publication No. 23: 583-592.

Decaulne A. \& Sæmundsson Th., 2008. Dendrogeomorphology as a tool to unravel snow-avalanche activity; preliminary results from the Fnjóskadalur test site, Northern Iceland. Norwegian Journal of Geography 62: 55-65.

Decaulne A., SÆmundsson Th. \& JónSSON H.P., 2008. Extreme runout distance of snow-avalanche transported boulders linked to hazard assessment; some case studies in Northwestern and Northern Iceland. In: Jóhannesson T. \& Hestnes E. (eds.), International Symposium on Mitigative
Measures against Snow Avalanches, Egilsstaðir, Iceland: 131-136.

Decaulne A. \& SÆmundsson Th., 2010. Distribution and frequency of snow-avalanche debris transfer in the distal part of colluvial cones in Central North Iceland. Geografiska Annaler A 92(2): 177-187.

Decaulne A., SÆmundsson Th. \& Jónsson H.P., 2009. An overview of postglacial sediment records from colluvial accumulations in Northwestern and North Iceland. Arctic, Antarctic and Alpine Research 41(1): 37-47.

Dingle S.A., Marenssi S.A. \& Lavelle M., 1998. High latitude Eocene climate deterioration: evidence from the northern Antarctic Peninsula. Journal of South American Earth Sciences 11: 571-579.

Environment Canada, 2008. Adjusted Historical Canadian Climate Data, http:/ / www.cccma.ec.gc.ca/hccd/

FARETH O.W., 1987. Glacial geology of the Middle and Inner Nordfjord, western Norway. Norges Geologiske Undersøkelse Bulletin 408: $55 \mathrm{p}$.

Forbes, A.C. \& Lamoureux, S.F., 2005. Climatic controls on streamflow and suspended sediment transport in three large middle arctic catchments, Boothia Peninsula, Nunavut, Canada. Arctic, Antarctic and Alpine Research 37: 305-315.

Gintz D., Beylich A.A., Zippel B. \& Laute K., 2008. Detection of stable and mobile channel units using biofilm analysis in cold environments. Geophysical Research Abstracts, Vol. 10, EGU2008-A-03877, 2008.

Hansen L., Beylich A.A., Burki V., Eilertsen R., Fredin O., Larsen E., Lyså A., Nesje A, Stalsberg K. \& Tønnesen J.F., 2009. Stratigraphic architecture and infill history of a deglaciated bedrock- -valley based on georadar, seismic profiling and drilling. Sedimentology 56: 1751-1773.

Hansen L. , Burki V., Stalsberg K., Derron M.-H., Eilertsen R., Fredin O., Larsen E., Lyså A., Nesje A. \& Tønnesen, J.-F., 2006. Towards a quantification of long-term valleyfill accumultation of a deglaciated fjord-valley system, Nordfjord, Norway. NGF Abstracts and Proceedings of the Geological Society of Norway 4: 46.

HaRDY D.R., 1996. Climatic influences on streamflow and sediment flux into Lake C2, northern Ellesmere Island, Canada. Journal of Paleolimnology 16: 133-149.

Hodgson D.A., Vincent J.-S. \& Fyles J.G., 1984. Quaternary geology of central Melville Island, Northwest Territories, Geological Survey of Canada Paper 83-16, Ottawa.

I.A.G. / A.I.G. SEDIBUD Working Group, 2008: March 2010, http://www.geomorph.org/wg/wgsb.html

LAFReniĖre M.J. \& LAMOUReuX S.F. , 2008. Seasonal dynamics of dissolved nitrogen exports from two High Arctic watersheds, Melville Island, Canada. Hydrologic Research 39: 323-335.

Lamoureux S.F., Beylich A.A. \& Decaulne, A., 2007. Sediment Fluxes and Budgets in Changing High-Latitude and High-Altitude Cold Environments. Sediment Budgets in Cold Environments (SEDIBUD) Second Workshop; Abisko, Sweden, 15-19 September 2007. EOS, Volume 88 (52), 25 December 2007: 580.

LAMoureux S.F. \& LAFrenière M.J., 2009. Fluvial impact of extensive active layer detachments, Cape Bounty, Melville Island, Canada. Arctic, Antarctic and Alpine Research 41: 59-68.

Lamoureux S.F., McDonald D.M., Cockburn J.M.H., LaFRENIÈRe M.J., AtKInSON D. \& TreitZ, P., 2006. An incidence of multi-year sediment storage on channel snowpack in the Canadian High Arctic. Arctic 59: 381-390. 
LARSEN E. \& MANGerud J., 1981. Erosion rate of a Younger Dryas cirque glacier at Kråkenes, western Norway. Annals of Glaciology 2: 153-158.

Laute K. \& Beylich A.A., 2010. Characteristics of floodplain deposits within a braided sandur system in upper Erdalen (Nordfjord, western Norway). Geografiska Annaler A 92(2): 211-223.

Laute K., Beylich A.A., Hansen L. \& Vatne G., 2010. Postglacial hillslope development in paraglacial tributary catchments (ESF-NFR SedyMONT-Norway Project, SedyMONT, Topo-Europe). Geophysical Research Abstracts 12, EGU2010.

Levanic T. \& Eggertsson O., 2008. Climatic effects on birch (Betula pubescens Ehrh.) growth in Fnjóskadalur valley, northern Iceland. Dendrochronologia 25: 135-143.

Liermann S., Beylich A.A., Rubensdotter L. \& Hansen L., 2010. Holocene to contemporary fluvial sediment budgets in small glacier-fed valley-fjord systems. (ESF-NFR SedyMONT-Norway Project, SedyMONT, TOPO-EUROPE). Geophysical Research Abstracts 12, EGU2010.

McDonald D.M. \& Lamoureux S.F., 2009. Multi-year suspended sediment transport, grain size and hysteresis characteristics in a High Arctic catchment. Earth Surface Processes and Landforms 34: 424-436.

Molau U. et al., 2001. Tundra plant responses to experimental and natural temperature changes. Memoirs of National Institute of Polar Research Special Issue: 445-466.

NesJE A., 1984. Kvartærgeologiske undersøkningar i Erdalen, Stryn, Sogn og Fjordane. Hovudfagsoppgave / Master thesis, University of Bergen: $201 \mathrm{p}$.
Nesje A. \& Kvamme M. 1991. Holocene glacier and climate variations in western Norway: evidence for early Holocene glacier demise and multiple Neoglacial events. Geo$\log y$ 19: 610-612.

Nesje A., Kvamme M., Rye N., \& Løvlie R, 1991. Holocene glacial and climate history of the Jostedalsbreen region, western Norway, evidence from lake sediments and terrestrial deposits. Quaternary Science Reviews 10: 87-114.

Nesje A., Dahl S.O., Andersson C. \& Matthews J.A., 2000. The lacustrine sedimentary sequence in Sygneskarvatnet, western Norway: a continuous, high resolution record of the Jostedalsbreen ice cap during the Holocene. Quaternary Science Reviews 19: 1047-1065.

Nesje A., Matthews J.A., Dahl S.O., Berrisford M.S. \& ANDERSSON C., 2001. Holocene glacier fluctuations of Flatebreen and winter-precipitation changes in the Jostedalsbreen region, western Norway, based on glacio-lacustrine sediment records. The Holocene: 267-280.

STEVENSON R., 2007. How currents of different size of substrates in streams affect mechanisms of benthic algal accumulation. Hydrobiology and Hydrogeography 69(2): 241-262.

Vatne G., Naas Ø.T., Skarholen T., Beylich A.A. \& Berthling I., 2008. Bedload transport in a steep snowmelt-dominated mountain stream as inferred from impact sensors. Norwegian Journal of Geography 62(2): 66-74.

WACHE S. \& BeYLICH A.A., 2006. Investigations on the dynamics and sediment budget of a braided river system in Erdalen, Nordfjord, western Norway. NGF Abstracts and Proceedings of the Geological Society of Norway 4: 70. 